\title{
Integrase inhibitors effective against human T-cell leukemia virus type 1
}

\author{
Muhammad E Seegulam, Lee Ratner ${ }^{*}$ \\ From 15th International Conference on Human Retroviruses: HTLV and Related Viruses \\ Leuven and Gembloux, Belgium. 5-8 June 2011
}

Drugs targeting the viral enzyme integrase have been in use for several years as part of the treatment regimen for patients with Human Immunodeficiency Virus Type 1 (HIV-1) and similar classes of compounds have been shown to inhibit Human T-Cell Leukemia Virus Type 1 (HTLV-1) integration in vitro. The current study shows that the clinically approved HIV-1 integrase inhibitor, Raltegravir, as well as the more recent diketo acid derivative, MK-2048, are active inhibitors of HTLV-1 infection in vitro. These agents were effective in inhibiting cell-free and cell-to-cell transmission of HTLV-1 in lymphoid and non-lymphoid cells. The drugs also inhibited HTLV-1 immortalization of human peripheral blood mononuclear cells. A novel adaptation of the Alu assay for viral integration was used to show that the drugs inhibit viral integration without affecting reverse transcription. These data support the administration of Raltegravir and other integrase inhibitors as treatments for patients with HTLV-1 associated diseases.

Published: 6 June 2011

doi:10.1186/1742-4690-8-S1-A34

Cite this article as: Seegulam and Ratner: Integrase inhibitors effective against human T-cell leukemia virus type 1. Retrovirology 2011 8(Suppl 1): A34.

\footnotetext{
* Correspondence: Iratner@dom.wustl.edu

Division of Molecular Oncology, Washington University, St Louis, MO, 63110, USA
}

Submit your next manuscript to BioMed Central and take full advantage of:

- Convenient online submission

- Thorough peer review

- No space constraints or color figure charges

- Immediate publication on acceptance

- Inclusion in PubMed, CAS, Scopus and Google Scholar

- Research which is freely available for redistribution

\section{() Biomed Central}

\section{Biomed Central}

